\title{
AMELIORATIVE EFFECT OF SPIRULINA PLATENSIS AGAINST DICLOFENAC SODIUM-INDUCED HEPATOTOXICITY IN BROILERS: HEMATOLOGICAL, BIOCHEMICAL, ANTIOXIDANT, IMMUNOLOGICAL AND HISTOPATHOLOGICAL STUDY
}

\author{
ABD-ALLAH A. MOKHBATLY ${ }^{1}$; EMAD W. GHAZY ${ }^{1}$; DOAA H. ABDELHADY ${ }^{1}$; \\ ABDO WALIED $^{2}$ and MARWA ABDELWAHAB ${ }^{1}$ \\ ${ }^{1}$ Clinical Pathology Department, Faculty of Veterinary Medicine, Kafrelsheikh University, Egypt. \\ ${ }^{2}$ Pathology Department, Faculty of Veterinary Medicine, Kafrelsheikh University, Egypt.
}

Received: 7 November 2017; $\quad$ Accepted: 3 December 2017

\begin{abstract}
Spirulina is one of the most commonly used dietary supplements in humans, aquaculture, aquarium, and recently in poultry industries and gained more attention to be used as a nutritional and therapeutic strategy. The present study has been carried out to investigate the effect of oral supplementation of Spirulina platensis in alleviating the hepatotoxic effect of diclofenac sodium through evaluating the hematological, biochemical, antioxidant parameters as well as immunological and histopathological studies. One hundred broiler chicks were divided into four groups (25 per each). The first group was fed on basal diet and treated with propylene glycol $(2.5 \mathrm{mg} / \mathrm{kg}$, i.m) (Control negative). The second group was fed on basal diet and injected with diclofenac sodium at dose (2.5 $\mathrm{mg} / \mathrm{kg}$.b.wt., i.m) (Control positive). The third group was injected with diclofenac sodium and then concurrently supplemented with Spirulina at dose $(10 \mathrm{gm} / \mathrm{kg}$ in their diet). The fourth group was fed on Spirulina two weeks before injection of diclofenac sodium at dose $(2.5 \mathrm{mg} / \mathrm{kg}$, i.m). Haematological data revealed that diclofenactreated chicks showed normocytic normochromic anemia, significant leucopenia and decrease the absolute number of heterophils and lymphocytes. Significant increase in serum biochemical parameters related to liver injury such as AST and ALP, total cholesterol and significant decrease in the levels of serum total proteins and albumin. Significant increase in uric acid level was also noticed. Furthermore, significant increase of oxidative damage biomarkers such as MDA and NO and significant decrease of the antioxidant enzymes as CAT, SOD and TAC. Moreover, diclofenac sodium has immunosuppressive effect through depressed phagocytic activity, phagocytic index and marked decrease in the titer of antibodies formed in chicks against Newcastle disease. Histopathological findings marked hepatic tissue damage due to gouty tophi lesions accompanied with presence of multifocal necrotic areas. Oral supplementation of Spirulina markedly decrease the histopathological alteration on preventive basis. Therefore, Spirulina supplementation markedly alleviated the deteriorating effects of diclofenac sodium-induced hepatotoxicity which mimics the gouty lesions in birds either on therapeutic or preventive regimes.
\end{abstract}

Key words: Spirulina, antioxidant, Diclofenac sodium, hepatoprotective.

\section{INTRODUCTION}

Poultry liver damage is a common disease clinically and can induce low performance and even death, and has caused a great economic loss in poultry industry as liver plays an important role in detoxification and excretion of many endogenous compounds so liver diseases mangement is still challenge to modern scientific community (Sunilson et al., 2009).

Corresponding author: Dr. DOAA H. ABDELHADY

E-mail address: doaa_assar2000@yahoo.com

Present address: Clinical Pathology Department, Faculty of

Veterinary Medicine, Kafrelsheikh University, Egypt.
Chemicals that induce liver injury are termed hepatotoxins, and more than nine hundred drugs have been implicated in causing liver damage which is the most common reason for a drug to be inhibited from the market (Bakke et al., 1995). Diclofenac is a phenyl acetic acid derivative and is mostly available in the form of diclofenac sodium. Diclofenac has been proven as an anti-inflammatory, analgesic and antipyretic properties with severe pathologic conditions such as peptic ulceration, gastrointestinal bleeding. Further more, diclofenac was found to be causing hepatotoxicity, renal papillary necrosis and renal failure on long term administration of the drug in poultry (Swetha et al., 2005) and (Prakash et al., 2006). 
Spirulina is filamentous microalgae belonging to the class of cyanobacteria with characteristic photosynthetic capability (Ismail et al., 2009). Earlier studies were mainly concentrated on the nutritional values of spirulina with its high protein content (60$70 \%$ by dry weight) (Hosseini et al., 2013). Recently, the antioxidant and/or anti-inflammatory activities of spirulina or its extract have become an interesting point for many researchers either in vitro or in vivo suggesting its beneficial effects as feed additive (Rasool et al., 2006); (Abdel-Daim et al., 2013; Luo et al., 2017; Wu et al., 2016). Furthermore, spirulina has been reported to ameliorate tissue toxicities induced by heavy metals (Ponce-Canchihuaman et al., 2010). Consequently, the current work was done to study the effect of oral supplementation of spirulina in alleviating the hepatoxicty experimentally induced by diclofenac sodium in broiler chicks through evaluation effect of spirulina on hematological, biochemical, antioxidant parameters as well as immunological and histopathological studies.

\section{MATERIALS AND METHODS}

\section{Chemicals:}

Diclofenac sodium was purchased from Egyptian pharmaceutical industries co (E.I.P.I.Co). Egypt Propylene glycol was purchased from El-Nasr pharmaceutical chemicals Co. Egypt. Spirulina platensis was purchased from the Algal Biotechnology unit, National Research Center, Dokki, Cairo, Egypt. (EDTA) was purchased from
(Salix), Natt and Herrick solution for WBCs and RBCs counts, Methyl alcohol (95\%) produced by pure Egypt. Co. Gemisa stains produced by HexaBiotech, Drabkins reagent (Vitro Scient) Egypt, Aspartate amino transferase (AST) and alkaline phosphates (ALP) purchased from Egyptian company for biotechnology (Spectrum), uric acid, cholesterol, albumin purchased from (Spinreact) Spain, total protein obtained from Diamond Diagnostic Company Kits-Egypt. All others chemicals used in the experiment were of analytical grade.

\section{Animals and experimental design:}

One hundred broiler chicks (Cobb breed) one day old were obtained from a local hatchery. Chicks were reared for 7 days for adaptation then divided randomly into 4 groups ( 25 birds per group). $1^{\text {st }}$ group fed on basal diet and treated with propylene glycol $(2.5 \mathrm{mg} / \mathrm{kg})$ i.m (Control negative), $2^{\text {nd }}$ group fed on basal diet injected with diclofenac sodium at dose (2.5 mg/kg.b.wt. i.m) (Mohan et al., 2012) (Control positive), $3^{\text {rd }}$ group fed on basal diet then at 21 days old treated with diclofenac sodium at dose $2.5 \mathrm{mg} / \mathrm{kg}$, i.m concurrently with Spirulina at dose $10 \mathrm{gm} / \mathrm{kg}$. (Therapeutic), $4^{\text {th }}$ group fed on spirulina two weeks before injection of diclofenac sodium at dose (2.5 $\mathrm{mg} / \mathrm{kg}$ ) i.m, (Preventive group).

All groups had free access to diet and water throughout the duration of the experiment and were kept under standard management conditions. All birds were routinely vaccinated against Newcastle disease at 7 and 18 days old and against IBD at 14 days old.

Table 1:

\begin{tabular}{cccc}
\hline Groups & Propylene glycol & Diclofenac sodium & Spirulina treatment \\
\hline Control(-ve) & + & - & - \\
\hline Control(+ve) & - & + & - \\
\hline Therapeutic (T) & - & + & + \\
\hline Preventive(p) & - & + & + \\
\hline
\end{tabular}

Time of diclofenac treatment: at 21 days of age old for 3 days.

\section{Hematological examination:}

Blood samples were collected two weeks after the last dose of injection and immediately divided in to three aliquots, one containing (EDTA) as anticoagulant and subdivided in to two parts one kept at $\left(-80^{\circ} \mathrm{C}\right)$ for estimation of Malonaldialdehyde (MDA), Catalase, Superoxide dismutase (SOD), Nitric Oxide (NO), Total antioxidant capacity (TAC) and the other part for hematological parameters (RBCs, PCV, Hb, mean cell volume (MCV), mean corpuscular hemoglobin $(\mathrm{MCH})$, mean corpuscular hemoglobin concentration (MCHC, WBCs and Differential leukocytic count) and $2^{\text {nd }}$ part collected on heparin $(20 \mathrm{IU} / \mathrm{ml})$ was used for separation of leukocyte for measurement of phagocytic activity.

\section{Serum collection and histopathology:}

The $3^{\text {rd }}$ part of blood sample was left to clot without anticoagulant at room temperature then centrifuged at $3000 \mathrm{rpm}$ for 5 minutes for separation of serum and stored at $\left(-20^{\circ} \mathrm{C}\right)$ and divided in to aliquots for biochemical assay.

After blood collection, chicks were sacrificed and liver sections were taken immediately from the liver, fixed in $10 \%$ buffered formalin. Then, dehydration, clearance and embedding in paraffin were carried out. Tissue sectioning and staining with $\mathrm{H} \& \mathrm{E}$ were performed according to (Bancroft et al., 1996). 


\section{Serum biochemical analysis:}

Freshly prepared serum used for estimation of serum liver injury biomarkers according to manufacture protocol; Aspartate amino transferase (AST) evaluated according to (Reitman and Frankel, 1957), alkaline phosphatase estimated according to (Thirunavukkarasu et al., 2003; Tietz et al., 1983), serum Albumin estimated according to (Chauhan and Chandra, 2007), serum total protein evaluated according to (Tietz et al., 1983), serum globulin concentration was obtained by subtracting the concentration of albumin from total proteins (Chauhan and Chandra, 2007) Albumin/ globulin ratio according to (Coles, 1986), serum cholesterol evaluated according to (Richmond, 1973) .

\section{Evaluation of oxidative stress and antioxidant biomarkers:}

Blood samples collected on EDTA for estimation of hepatic lipid peroxidation content by measuring of Malonaldialdehyde (MDA) according to (Esterbauer et al., 1982), serum Nitric oxide (NO) according to (Montgomery and Dymock, 1961) anti oxidative stress markers as Superoxide dismutase (SOD) according to (Packer and Glazer, 1990), Catalase (CAT) according to (Sinha, 1972) and total antioxidant capacity according to (Koracevic et al., 2001).

\section{Evaluation of some immunological parameters:} Including estimation of humoral immunity by using HI test against ND by using the standard microplate system described by(King and Seal, 1998) and determination of phagocytic activity and phagocytic index was performed according to the method described by (Wilkinson, 1981) .

\section{Statistical analysis:}

- All data were expressed as means \pm S.E. and statistically analyzed by one-way ANOVA and Tukey multiple comparisons using graphpad prism 5 software. Statistical significance was acceptable to a level of $\mathrm{P} \leq 0.05$.

\section{RESULTS}

\section{General Clinical Observations:}

The clinical symptoms in all the tested groups were observed daily. The control negative group did not show any clinical signs of toxicity or mortalities throughout the experimental period. Diclofenac treated group, showed severe clinical symptoms such as dullness, anorexia, ruffled feathers, laziness, depression, recumbency, sun ken eyes and high mortality rate $(64 \%)$. Therapeutic group showed moderate clinical signs this confirmed by the decrease in the percentage of mortality rate $(32 \%)$. Preventive group were apparently healthy and showed noticeable decrease in mortality rate $(8 \%)$.

\section{Effect on erythrogram:}

\subsection{Hematological parameters:}

The effects of diclofenac treatment as well as the therapeutic and preventive effects of spirulina on erythrogram are shown in table (2) and figures (1, 2, 3, 4, 5, and 6). Blood parameters (RBCs, $\mathrm{Hb}$ and PCV) showed significant $(p \leq 0.05)$ decrease in diclofenac treated group as compared with control negative group. Contrary to these results, insignificant changes in blood indices (MCV, MCH and $\mathrm{MCHC}$ ) were observed. Whereas, simultaneous administration of spirulina with diclofenac treatment (Therapeutic group) induced pronounced increase in blood parameters (RBCs, $\mathrm{Hb}$ and $\mathrm{PCV}$ ) but still insignifican as compared with diclofenac treated group.. On the other hand, spirulina supplementation in preventive group significantly $(\mathrm{p} \leq 0.05)$ improves the lower hematological parameters (RBCs, Hb and $\mathrm{PCV}$ ) without significant changes in blood indices (MCV, MCH and MCHC) as compared with diclofenac treated group.

\section{2. Effect on Leukogram:}

The effect of diclofenac treatment as well as the therapeutic and preventive effects of spirulina on Leukogram was shown in table (3) and figures (7, 8, 9, 10, and 11). Data demonstrated significant ( $\mathrm{p}$ $\leq 0.05$ ) decrease in (WBCs, absolute number of heterophils, lymphocytes and monocytes) in diclofenac treated group compared with control negative group. While insignificant changes in (absolute number of eosinophils) were recorded. Meanwhile, Co-administration of spirulina with diclofenac treatment (therapeutic group) revealed prominent increase in (WBCs and absolute number of heterophils) but still insignificant as compared with diclofenac treated group. In addition, insignificant changes in (absolute number of esinophils and monocytes) were observed as compared with diclofenac treated group. On the other side, significant $(p \leq 0.05)$ increase in absolute number of lymphocytes was recorded as compared with diclofenac treated group. Contrary to these result pretreatment with spirulina in preventive group showed significant $(\mathrm{p} \leq 0.05)$ increase in (WBCs, absolute number of lymphocytes, eosinophils and monocytes) without significant changes in absolute number of heterophils were observed as compared with diclofenac treated group.

\section{Serum biochemical analysis:}

The effects of diclofenac treatment as well as the therapeutic and preventive effects of spirulina on serum biochemical analysis are shown in table (4) and figures $(12,13,14,15,16,17,18$ and 19). Data explored that significant $(p \leq 0.05)$ increase in serum liver function marker enzymes (AST and ALP) in diclofenac treated group as compared to control negative group. Similarly, significant $(p \leq 0.05)$ increase in uric acid and cholesterol. Mean while, 
significant $(p \leq 0.05)$ decrease in total proteins, albumin and globulins compared with control nontreated group. While, diclofenac sodium had no effect on $\mathrm{A} / \mathrm{G}$ ratio. Moreover, concurrent administration of spirulina with diclofenac treatment (therapeutic group) showed marked decrease in (AST, ALP, uric acid, cholesterol) but still insignificant as compared with diclofenac treated group. On the other hand, pronounced increase in total proteins, albumin, and globulins were recorded but remain had no effect as compared with diclofenac treated group. Concerning spirulina supplementation in preventive group, AST, ALP, uric acid and cholesterol were significantly ( $p$ $\leq 0.05$ ) decreased. On the contrast spirulina supplementation induced significant increase in total proteins, albumin, and globulins without significant changes in $\mathrm{A} / \mathrm{G}$ Ratio as compared with diclofenac group.

\section{Lipid perioxidation by oxidative stress and antioxidant biomarkers:}

Data obtained from table (5) and Fig. (20, 21, 22, 23 and 24) explored the effects of spirulina supplementation and/or diclofenac treated groups on oxidative stress and antioxidant parameters. Data reflected that significant $(\mathrm{p} \leq 0.05)$ increase in MDA and NO content were observed in diclofenac treated group as compared to control negative group. On the other hand, CAT, SOD, TAC were significantly ( $\mathrm{p}$ $\leq 0.05$ ) decreased compared with the control negative group. However, Co administration of spirulina with diclofenac sodium (therapeutic group) showed marked decrease in (MDA and NO) but still insignificant in comparison with diclofenac treated chicks. While, pronounced increase in (CAT, SOD and TAC) which remain had no effect as compared with diclofenac treated group. Regarding to preventive group, MDA and NO were significantly ( $p$ $\leq 0.05$ ) decreased while, CAT, SOD and TAC were significantly $(\mathrm{p} \leq 0.05)$ increased in comparison with diclofenac treated chicks.

\section{Immunological parameters:}

The effects of diclofenac treatment as well as the therapeutic effect of spirulina Platensis on some of immunological are shown in table (6) and figures (25, 26 and 27). Data demonstrated that significant ( $p$ $\leq 0.05$ ) decrease in phagocytic activity, phagocytic index and HI antibody against Newcastle were observed in diclofenac treated group as compared with the control negative group. Meanwhile, coadministration of diclofenac sodium with spirulina supplementation in therapeutic group showed significant $(p \leq 0.05)$ increase in phagocytic activity, phagocytic index and HI antibody against Newcastle recorded in therapeutic group compared with the diclofenac treated group. Furthermore, spirulina platensis supplementation in preventive group induced significant $(\mathrm{p} \leq 0.05)$ increase in phagocytic activity, phagocytic index and HI antibody against Newcastle) in preventive group compared with the diclofenac treated group.

\section{Histopathological findings:}

As shown in fig (28), liver of chicken belonging to the control negative showed normal hepatocytes arranged in cords mostly in acinar-like appearance around centrally located central vein. Liver of chickens belonging to the control positive revealed marked congestion of hepatic blood sinusoids, sinusoidal cell activation and multifocal hepatic degeneration. There was multifocal areas of urate crystal deposition associated with necrosis of hepatic tissue. In addition, coagulative necrosis and focal aggregation of large number of mononuclear cells were noticed. However, the liver of therapeutic group revealed only vacuolation of hepatocytes, with periportal single hepatic cell degeneration. Similarly, the Preventive group showed normal hepatocytes, mild degree of periportal degeneration and minimal mononuclear cells infiltration.

Table (2): Erythrogram (mean \pm SE) in control and different treated groups

\begin{tabular}{|c|c|c|c|c|}
\hline $\begin{array}{l}\text { group } \\
\text { Parameter }\end{array}$ & Control negative & Control positive & Therapeutic & Preventive \\
\hline RBCs $10^{6} / \mu 1$ & $3.76 \pm 0.13^{\mathrm{a}}$ & $3.05 \pm 0.12^{\mathbf{b}}$ & $3.09 \pm 0.06^{\mathbf{b}}$ & $3.57 \pm 0.07^{a}$ \\
\hline PCV \% & $31.6 \pm 1.63^{\mathrm{a}}$ & $26.6 \pm 0.67^{\mathbf{b}}$ & $27.6 \pm 0.98^{\mathbf{b}}$ & $30.0 \pm 0.44^{a b}$ \\
\hline $\mathrm{Hb} \mathrm{gm} / \mathrm{dl}$ & $13.6 \pm 0.38^{a}$ & $10.7 \pm 0.17^{\mathbf{b}}$ & $12.8 \pm 0.05^{\mathrm{a}}$ & $13.2 \pm 0.28^{a}$ \\
\hline $\mathrm{MCV}$ (fl) & $85.60 \pm 0.32^{\mathrm{a}}$ & $85.86 \pm 0.44^{\mathrm{a}}$ & $85.94 \pm 0.44^{\mathrm{a}}$ & $84.06 \pm 0.69^{a}$ \\
\hline $\mathrm{MCH} \mathrm{Pg}$ & $36.40 \pm 0.88^{a}$ & $35.30 \pm 1.56^{\mathrm{a}}$ & $40.04 \pm 1.32^{\mathrm{a}}$ & $37.20 \pm 0.72^{a}$ \\
\hline $\mathrm{MCHC} \%$ & $42.50 \pm 1.05^{\mathrm{a}}$ & $41.22 \pm 1.73^{\mathrm{a}}$ & $46.58 \pm 1.50^{\mathrm{a}}$ & $44.24 \pm 0.93^{a}$ \\
\hline
\end{tabular}

The data are presented as Means \pm SE; $(n=5)$. With in the same row different letters indicate statistical significance at $(\mathrm{p} \leq 0.05)$. 
Table (3): Leukogram (mean \pm SE) in control and different treated groups.

\begin{tabular}{|c|c|c|c|c|}
\hline $\begin{array}{l}\text { group } \\
\text { Parameter }\end{array}$ & Control negative & Control positive & Therapeutic & Preventive \\
\hline TLC $10^{3} / \mu 1$ & $29.6 \pm 1.16^{a}$ & $16.8 \pm 1.02^{b}$ & $21.4 \pm 3.15^{b}$ & $37.4 \pm 1.07^{\mathrm{c}}$ \\
\hline Heter. $10^{3} / \mu 1$ & $12.4 \pm 0.64^{a}$ & $6.9 \pm 0.50^{b}$ & $7.5 \pm 1.03^{b}$ & $9.6 \pm 0.37^{b}$ \\
\hline Lymph. $10^{3} / \mu 1$ & $15.1 \pm 0.47^{\mathrm{a}}$ & $8.6 \pm 0.54^{\mathrm{a}}$ & $12.2 \pm 1.84^{\mathrm{ab}}$ & $25.0 \pm 0.84^{\mathrm{c}}$ \\
\hline Eosin. $10^{3} / \mu 1$ & $1.4 \pm 0.16^{\mathrm{a}}$ & $0.9 \pm 0.08^{a}$ & $1.2 \pm 0.24^{\mathrm{a}}$ & $2.1 \pm 0.20^{\mathrm{ab}}$ \\
\hline Mono. $10^{3} / \mu 1$ & $0.53 \pm 0.06^{\mathrm{a}}$ & $0.33 \pm 0.02^{b}$ & $0.38 \pm 0.07^{\mathbf{b}}$ & $0.59 \pm 0.09^{a}$ \\
\hline
\end{tabular}

The data are presented as Means \pm SE; $(n=5)$. With in the same row different letters indicate statistical significance at $(\mathrm{p} \leq 0.05)$.

Table (4): Serum biochemical parameter (mean \pm SE) in control and different treated groups.

\begin{tabular}{|c|c|c|c|c|}
\hline $\begin{array}{l}\text { group } \\
\text { parameter }\end{array}$ & Control negative & Control positive & Therapeutic & Preventive \\
\hline $\mathrm{ALP}(\mathrm{U} / \mathrm{L})$ & $99.06 \pm 5.25^{\mathrm{a}}$ & $256.6 \pm 8.99^{b}$ & $233.5 \pm 5.93^{b}$ & $120.6 \pm 2.86^{a}$ \\
\hline AST(U/L) & $86.3 \pm 3.36^{a}$ & $193.9 \pm 11.45^{\mathbf{b}}$ & $196.8 \pm 6.75^{b}$ & $114.0 \pm 2.99^{a}$ \\
\hline Uric $\operatorname{acid}(\mathrm{mg} / \mathrm{dl})$ & $6.2 \pm 0.23^{a}$ & $27.1 \pm 1.34^{\mathbf{b}}$ & $23.2 \pm 1.78^{\mathbf{b}}$ & $8.5 \pm 0.55^{\mathrm{a}}$ \\
\hline Chol.(mg/dl) & $129.6 \pm 5.13^{\mathrm{a}}$ & $180.06 \pm 6.10^{b}$ & $136.1 \pm 6.46^{a}$ & $91.3 \pm 5.41^{\mathrm{c}}$ \\
\hline Albumin(gm/dl) & $1.67 \pm 0.12^{a}$ & $1.25 \pm 0.07^{\mathbf{b}}$ & $1.23 \pm 0.02^{\mathbf{b}}$ & $1.67 \pm 0.03^{a}$ \\
\hline T. protein $(\mathrm{gm} / \mathrm{dl})$ & $5.64 \pm 0.38^{a}$ & $4.03 \pm 0.11^{\mathbf{b}}$ & $3.97 \pm 0.15^{\mathbf{b}}$ & $5.03 \pm 0.27^{\mathrm{a}}$ \\
\hline Globulin(gm/dl) & $3.97 \pm 0.35^{\mathrm{a}}$ & $2.78 \pm 0.07^{\mathbf{b}}$ & $2.74 \pm 0.16^{\mathbf{b}}$ & $3.89 \pm 0.11^{\mathrm{a}}$ \\
\hline $\mathrm{A} / \mathrm{G}$ ratio & $0.42 \pm 0.0 .04^{\mathrm{a}}$ & $0.44 \pm 0.02^{\mathrm{a}}$ & $0.45 \pm 0.03^{\mathrm{a}}$ & $0.48 \pm 0.04^{\mathrm{a}}$ \\
\hline
\end{tabular}

Data are expressed as Means $\pm S E ;(n=5)$, with in the same raw different letters indicates statistical significance at $(\mathrm{p} \leq 0.05)$.

Table (5): Antioxidant parameters (mean \pm SE) in control and different treated groups.

\begin{tabular}{lcccc}
\hline $\begin{array}{c}\text { group } \\
\text { parameter }\end{array}$ & Control negative & Control positive & Therapeutic & Preventive \\
\hline $\mathrm{MDA}(\mathrm{nmol} / \mathrm{ml})$ & $34.4 \pm 0.73^{\mathbf{a}}$ & $43.6 \pm 0.84^{\mathbf{b}}$ & $41.4 \pm 0.61^{\mathbf{b}}$ & $35.7 \pm 0.80^{\mathrm{a}}$ \\
\hline $\mathrm{NO}(\mu \mathrm{mol} / \mathrm{L})$ & $111.9 \pm 7.61^{\mathrm{a}}$ & $201.4 \pm 13.93^{\mathbf{b}}$ & $198.8 \pm 20.93^{\mathbf{b}}$ & $133.0 \pm 10.66^{\mathbf{a}}$ \\
\hline Catalase $(\mathrm{U} / \mathrm{L})$ & $1.44 \pm 0.03^{\mathrm{a}}$ & $1.07 \pm 0.06^{\mathbf{b}}$ & $1.16 \pm 0.01^{\mathbf{b}}$ & $1.50 \pm 0.04^{\mathrm{a}}$ \\
\hline $\mathrm{SOD}(\mathrm{U} / \mathrm{L})$ & $49.3 \pm 3.57^{\mathrm{a}}$ & $29.1 \pm 2.90^{\mathbf{b}}$ & $33.1 \pm 2.90^{\mathbf{b}}$ & $56.6 \pm 1.35^{\mathrm{a}}$ \\
\hline $\mathrm{TAC}(\mathrm{mM} / \mathrm{L})$ & $3.1 \pm 0.12^{\mathrm{a}}$ & $1.1 \pm 0.05^{\mathbf{b}}$ & $1.3 \pm 0.14^{\mathbf{b}}$ & $3.7 \pm 0.25^{\mathrm{a}}$ \\
\hline
\end{tabular}

The data are presented as Means \pm SE; $(n=5)$. With in the same row different letters indicate statistical significance at $(\mathrm{p} \leq 0.05)$.

Table (6): Some immunological parameters (mean \pm SE) in control and different treated groups.

\begin{tabular}{lcccc}
\multicolumn{1}{c}{$\begin{array}{l}\text { group } \\
\text { parameter }\end{array}$} & Control negative & Control positive & Therapeutic & Preventive \\
\hline Phag. activity & $46 \pm 2.51^{\mathrm{a}}$ & $36.6 \pm 1.99^{\mathrm{b}}$ & $50.4 \pm 1.53^{\mathrm{ac}}$ & $56.8 \pm 1.56^{\mathrm{c}}$ \\
\hline Phag. index & $2.93 \pm 0.10^{\mathrm{a}}$ & $2.80 \pm 0.15^{\mathrm{a}}$ & $3.40 \pm 0.10^{\mathrm{b}}$ & $3.54 \pm 0.09^{\mathrm{b}}$ \\
\hline HI Ab titer against Newcastle & $2^{6.6} \pm 0.60^{\mathrm{a}}$ & $2^{5.6} \pm 0.24^{\mathrm{b}}$ & $2^{7} \pm 0.44^{\mathrm{a}}$ & $2^{7.6} \pm 0.24^{\mathrm{a}}$ \\
\hline
\end{tabular}

The data are presented as Means \pm SE; $(n=5)$. With in the same row different letters indicate statistical significance at $(\mathrm{p} \leq 0.05)$. 


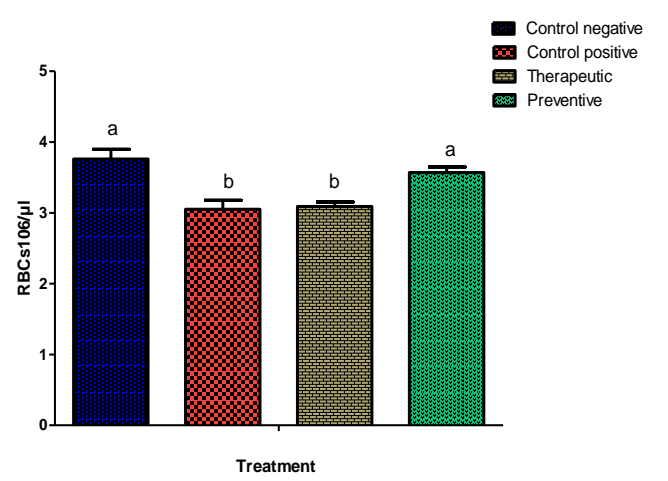

Fig (1): RBCs count in control and different treated groups

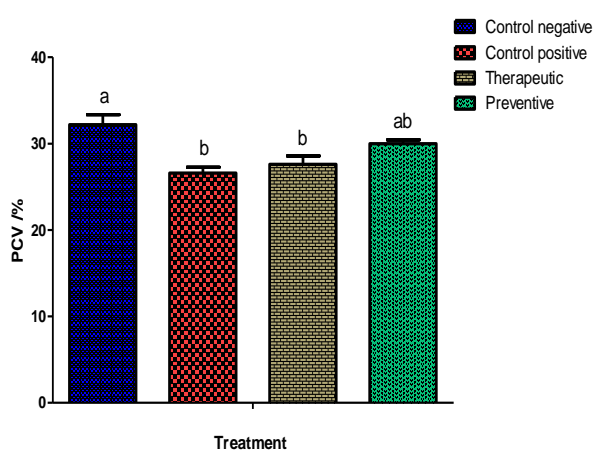

Fig (2): PCV\% in control and different treated groups
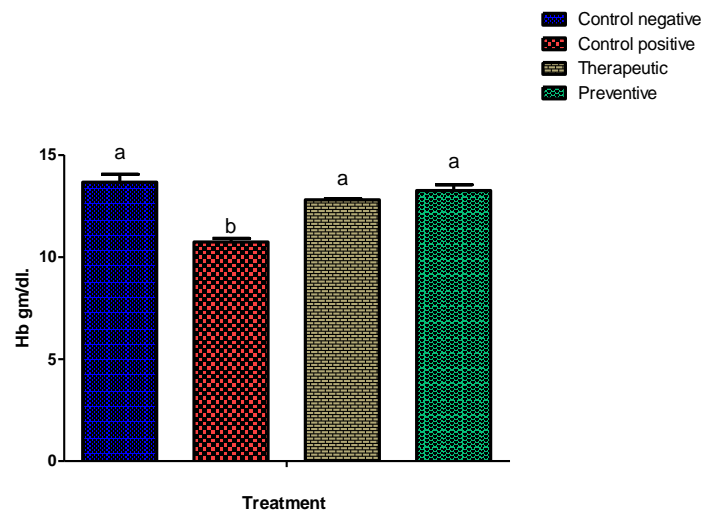

Fig (3): Hemoglobin (gm/dl) in control and different treated groups Fig (4): MCV/fl in control and different treated groups

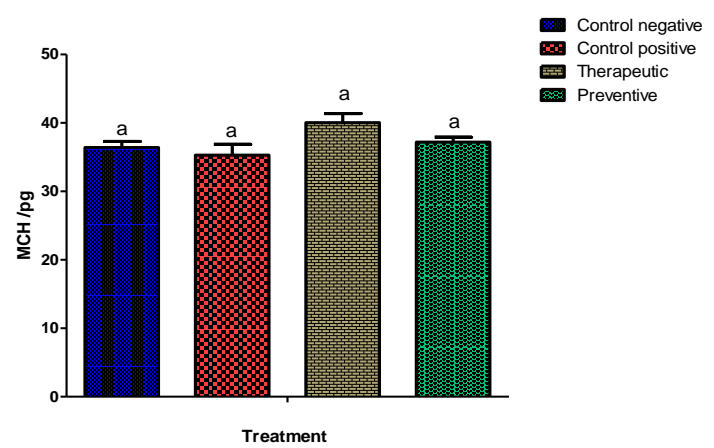

Fig (5): $\mathrm{MCH} / \mathrm{pg}$ in control and different treated groups
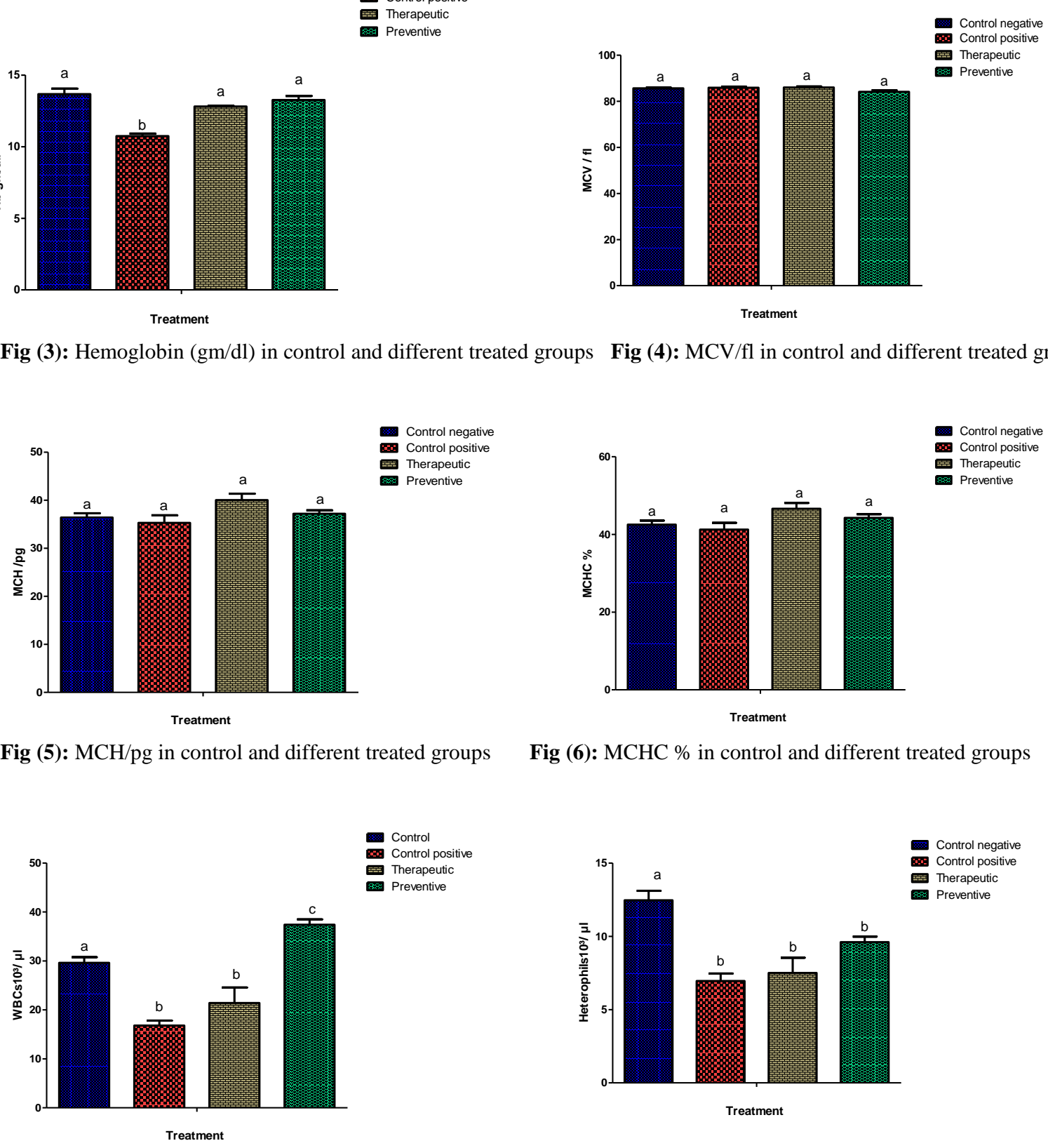

Fig (6): MCHC \% in control and different treated groups

Fig (7): WBCs $10^{3 /} \mu \mathrm{l}$ in control and different treated groups Fig (8): Heteropils $10^{3 /} \mu 1$ in control and different treated groups 

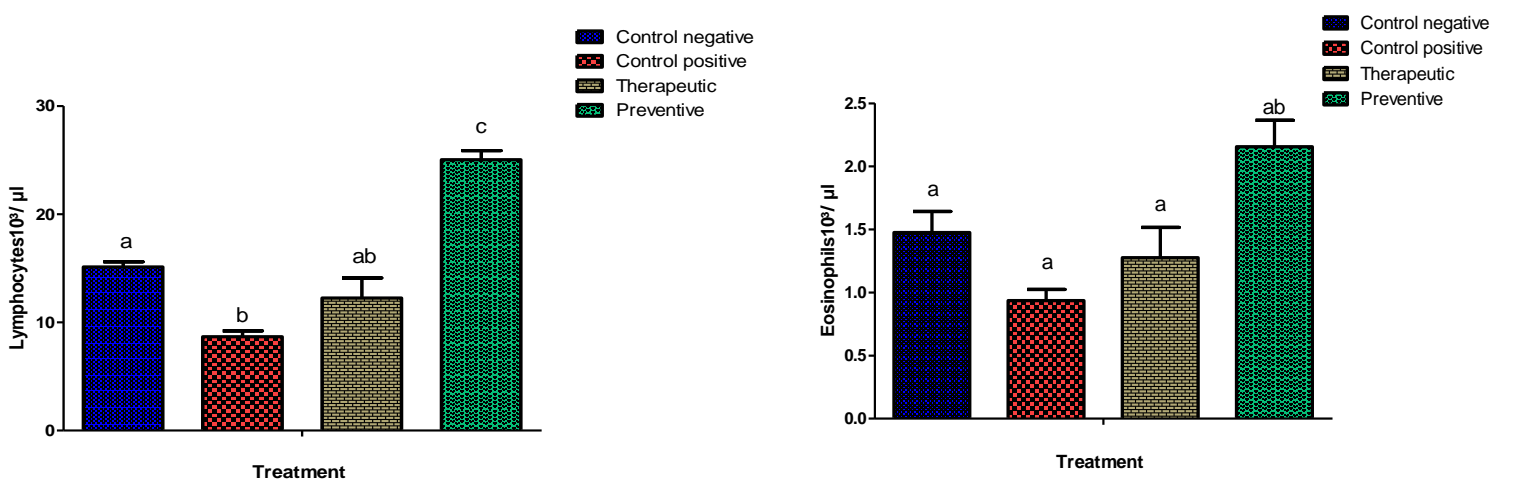

Fig (9): Lymphocytes $10^{3 /} \mu 1$ in control and different treated groups Fig (10): Eosinophils $10^{3 /} \mu 1$ in control and different treated groups

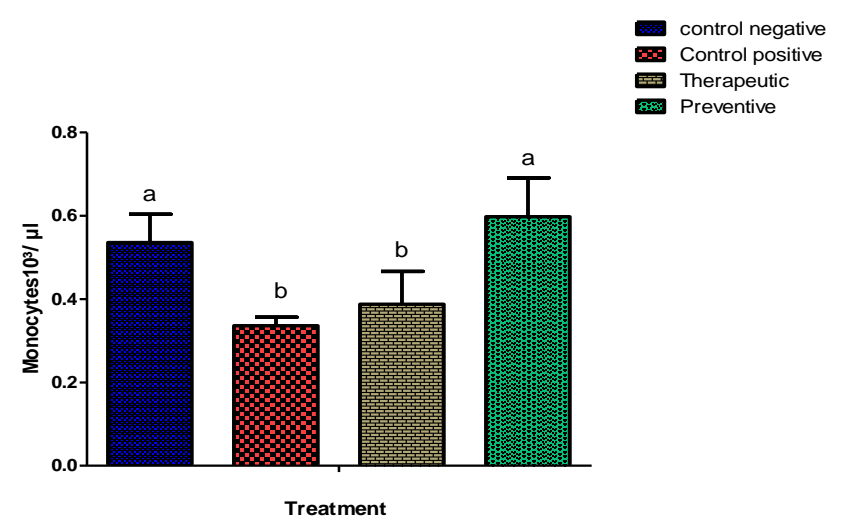

Fig (11): Monocytes $10^{3 /} \mu 1$ in control and different treated groups

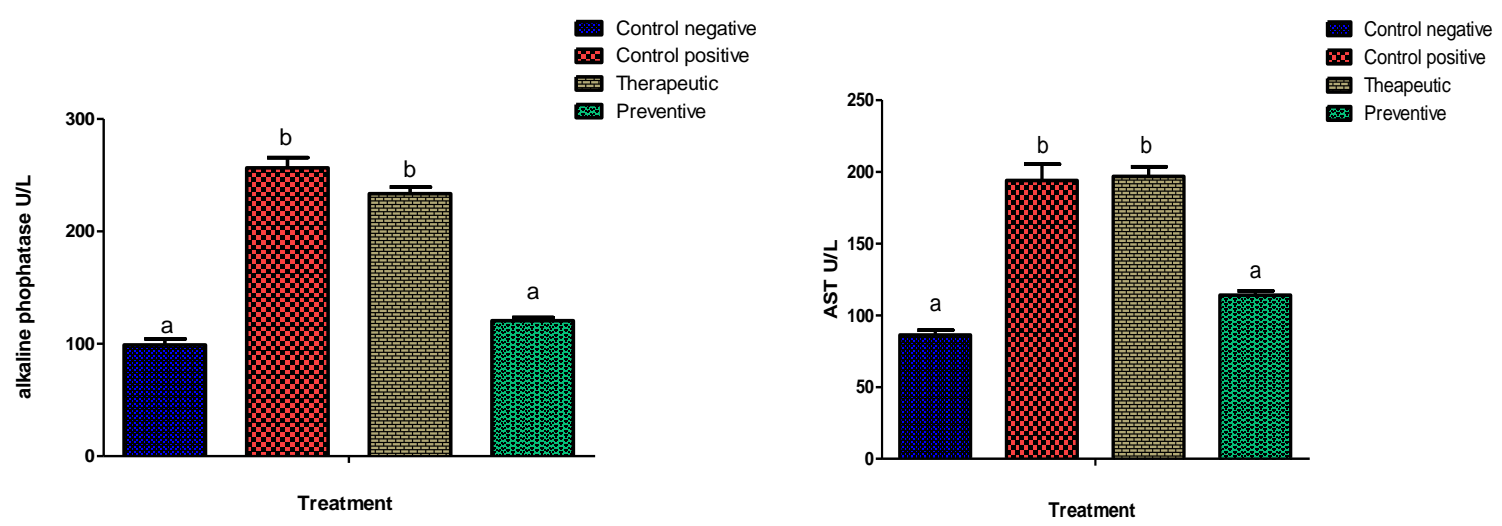

Fig (12): Serum alkaline phosphatase (U/L) in control and different treated groups

Fig (13): Serum AST (U/L) in control and different treated groups
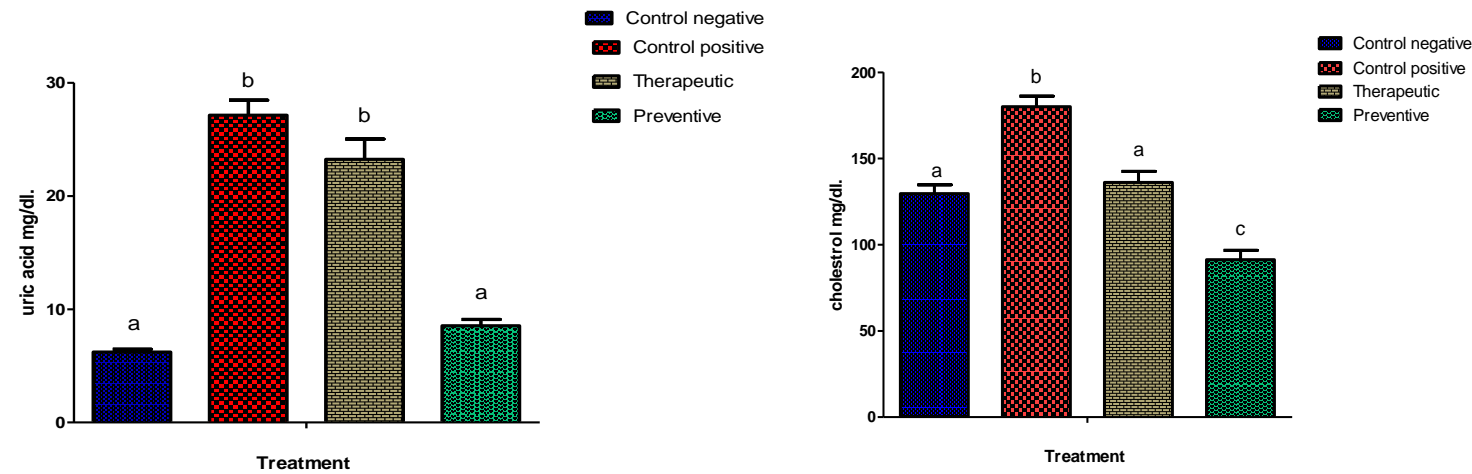

Fig (14): Serum uric acid (mg/dl) in control and different treated groups

Fig (15): Serum total cholesterol (mg/dl) in control and different treated groups 


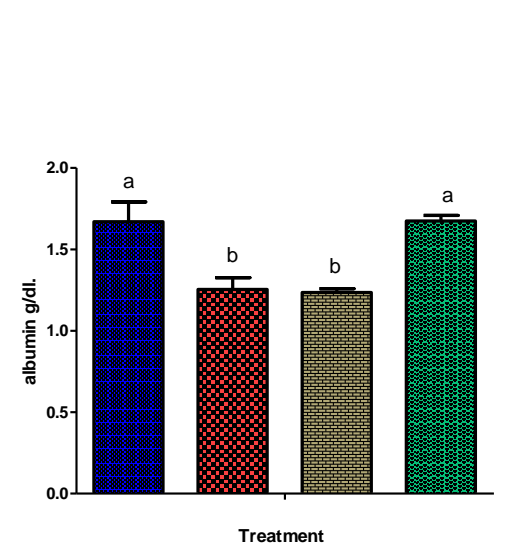

Fig (16): Serum albumin (gm/dl) in control and different treated groups

$$
\begin{aligned}
& \text { Control negative } \\
& \text { Control positive } \\
& \text { Therapeutic } \\
& \text { Preventive }
\end{aligned}
$$

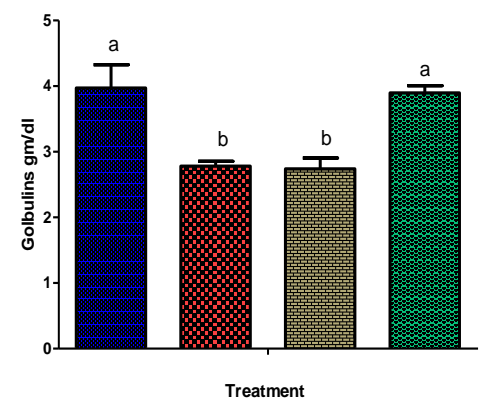

Fig (18): Serum Globulins (gm/dl) in control and different treated groups

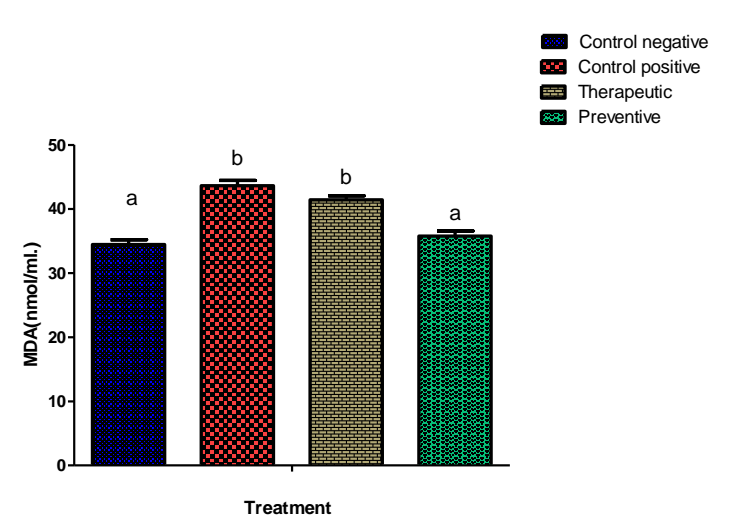

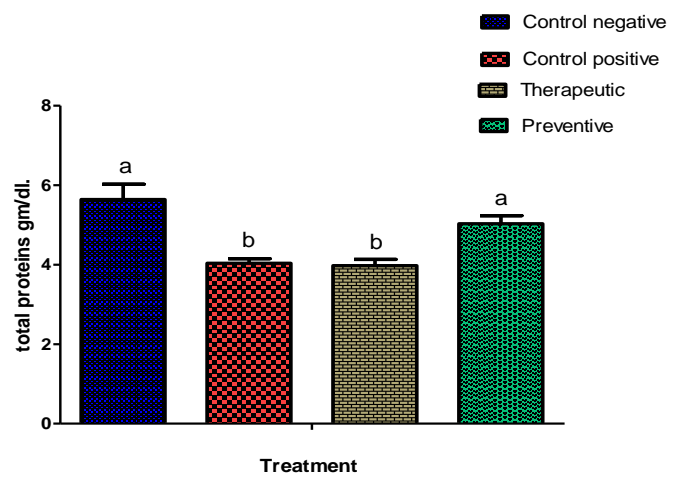

Fig (17): Serum total proteins ( $\mathrm{gm} / \mathrm{dl})$ in control and different treated groups

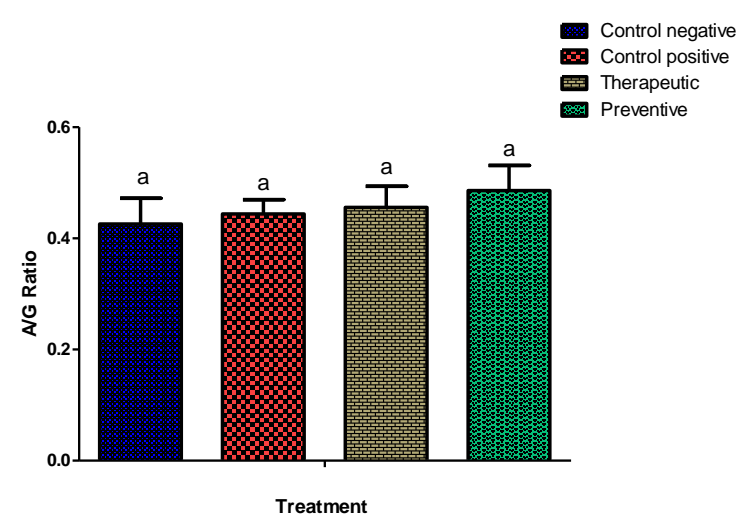

Fig (19): A/G ratio in control and different treated groups

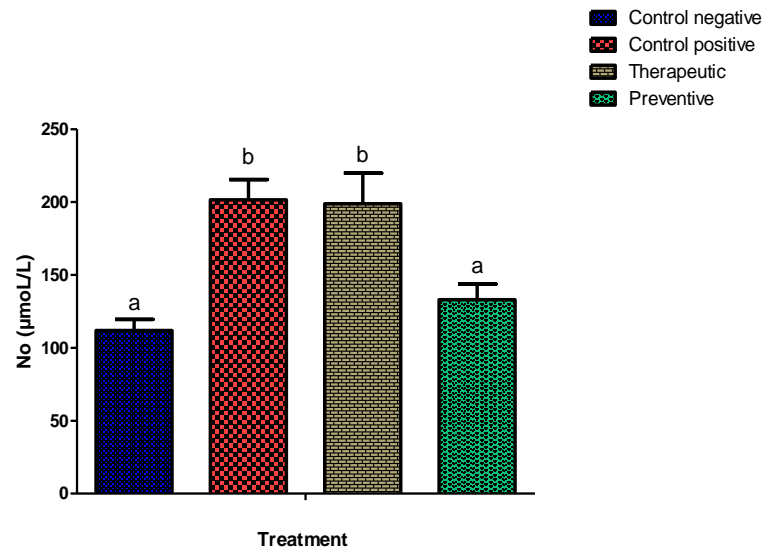

Fig (23): NO ( $\mu \mathrm{mol} / \mathrm{L})$ in control and different treated groups
Fig (20): MDA (nmol/ml) in control and different treated groups 

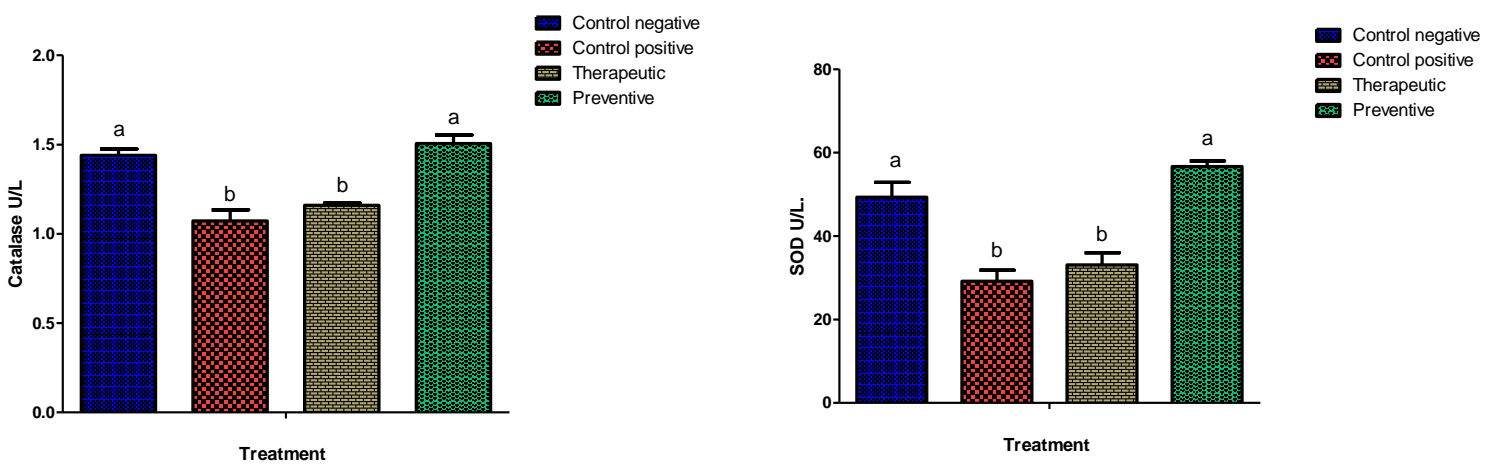

Fig (21): Catalase (U/L) in control and different treated groups Fig (22): SOD (U/L) in control and different treated groups

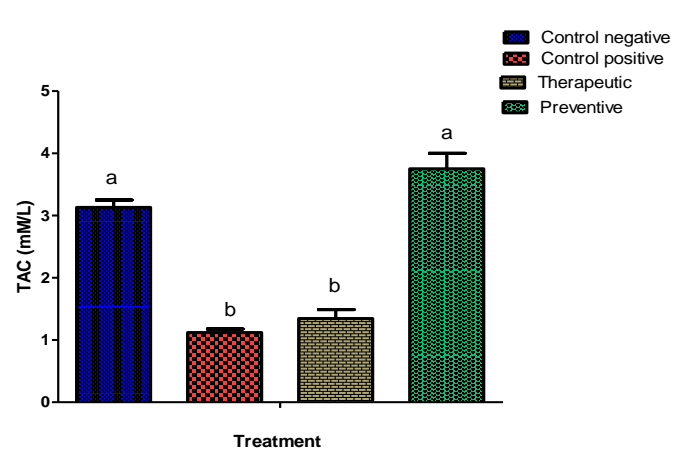

Fig (24): Total antioxidant capacity (mM/L) in control and different treated groups

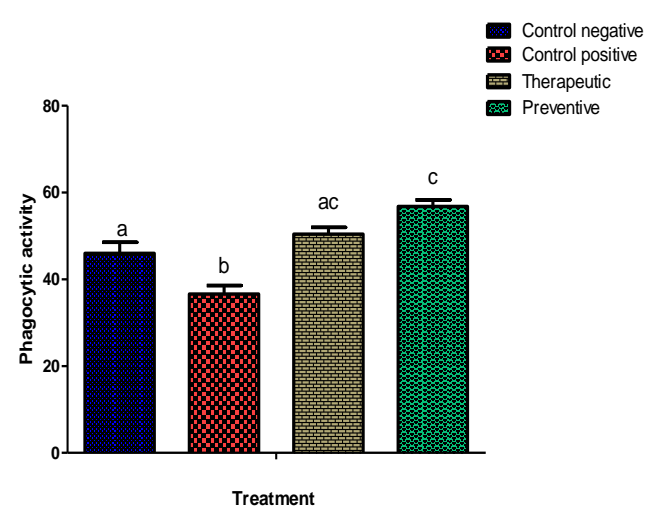

Fig (25): Phagocytic activity in control and different treated groups:

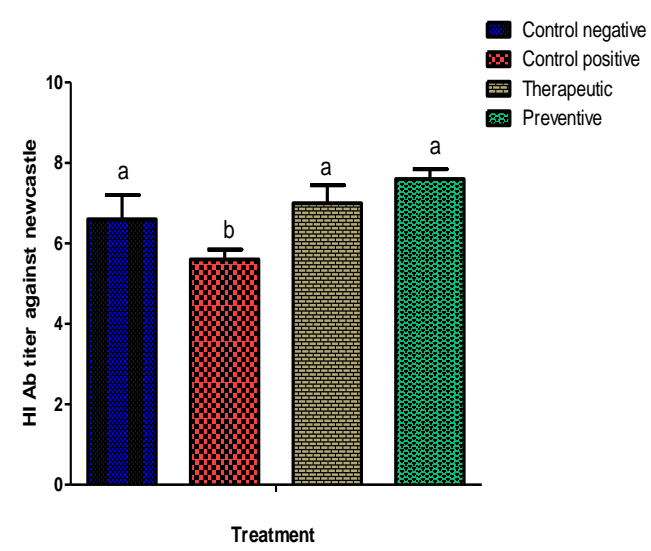

Fig (26): Phagocytic index in control and different treated groups
Fig (27): HI Ab titer against new castle in control and different treated groups 

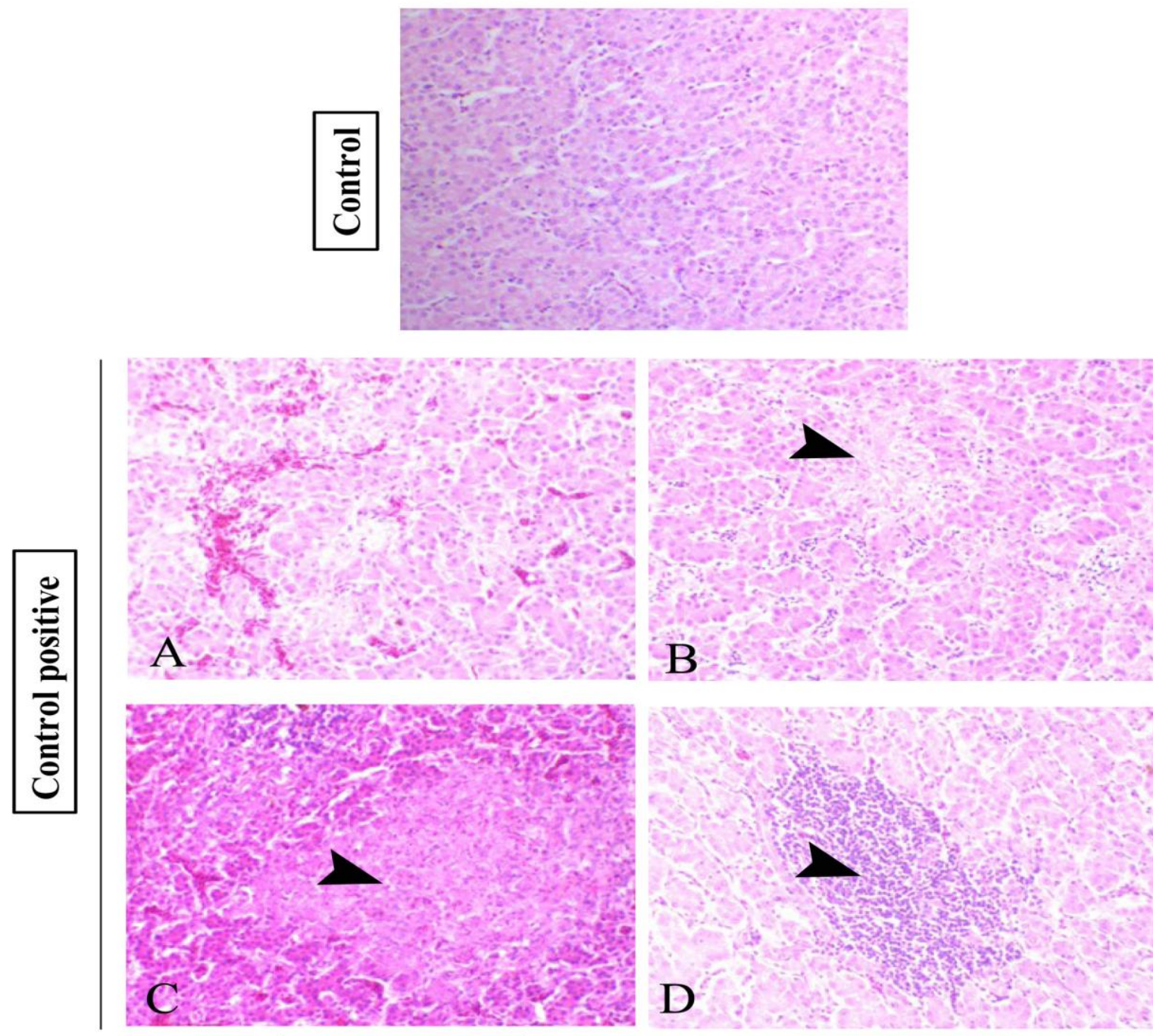

Therapeutic
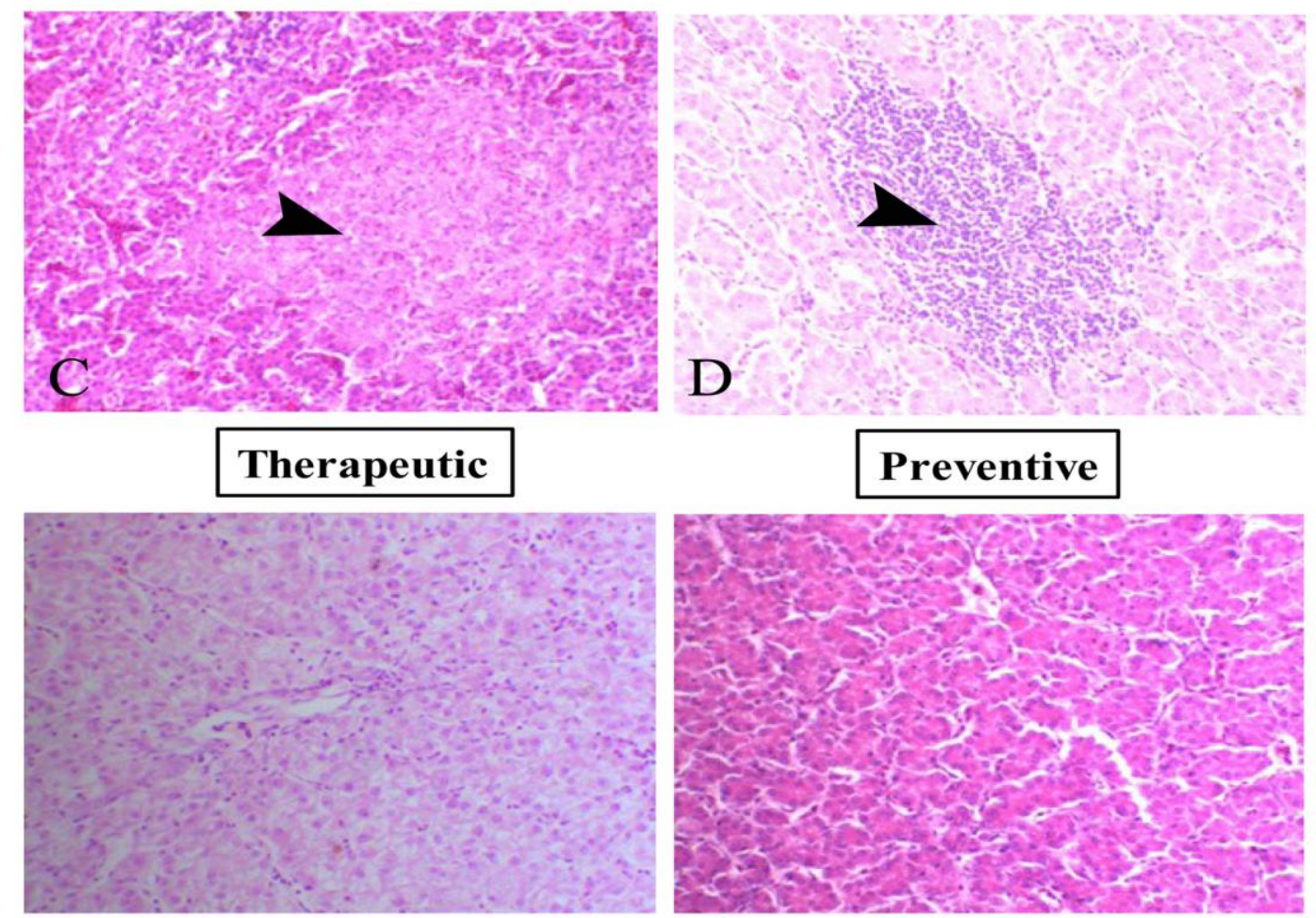

Fig. 28: Liver of normal chickens (control) showing normal hepatic tissues structures. Liver of (control positive group) showing congestion of blood sinusoids (A), hepatic degeneration and necrosis associated with of urate crystal deposition (arrowheads) (B), area of coagulative necrosis (arrowheads) (C) and focal mononuclear cell infiltration (arrowheads) (D). Liver of (Therapeutic group) showing mild vacuolar changes of hepatocytes. Liver of (preventive group) showing hepatocytes within the normal limit.

\section{DISCUSSION}

The present study aimed to investigate the effect of spirulina supplementation in alleviating the toxic effect of diclofenac sodium on hematological, biochemical, antioxidant biomarkers, immunological parameters and histopathological finding.
The clinical signs and high mortality rate detected in the diclofenac treated group could be referred to acute renal failure resulting in visceral gout, which was further evident from the histopathological lesions of the birds died during the experiment and these finding were in agreement with the findings of (Swan et al., 
2006; Swetha et al., 2005), whereas administration of spirulina in a therapeutic way to the diclofenac treated chicks lead to decrease in the percentage of mortality rate $(32 \%)$ as compared with diclofenac treated group. However, preventive treatment enabled more chicks with diclofenac sodium induced hepatotoxicity to survive. These results suggest that preventive treatment with spirulina plays crucial role in the prevention of the initial inflammation caused by diclofenac sodium treatment and this confirmed by lower mortality rate and histopathological findings.

Diclofenac sodium treatment significantly induced normocytic normochromic anemia, leucopenia and decrease in absolute number of heterophils (Sanchez et al., 2002), (Kenneth et al., 2003) and (Sachs et al., 2004). Similarly, diclofenac sodium treatment lead to hepatic damage as indicated by the increased serum level of AST, ALP, cholesterol level decreased total protein, albumin level (Yapar et al., 2008). Similarly, significant $(\mathrm{p} \leq 0.05)$ increase in uric acid concentration can be attributed to impaired uric acid excretion due to diclofenac-induced renal tubular degeneration, resulting in renal failure, leading to uric acid accumulation in blood and tissues and subsequent visceral gout (Eldin et al., 2008) and (Syed et al., 2012). Furthermore, levels of (MDA) and (NO) were significatly increased and depletion of SOD, CAT, TAC activities were detected (Venkateswaran and Pari, 2003) which resulted from generation of free radicals (benzoquinones imines) (Adebayo et al., 2010).

In the current study, spirulina supplementation played role in alleviating the incidence of anemia in preventive manner more potent than therapeutic manner. The ability to decrease incidence of anemia occur as spirulina posses' strong antioxidant and antiinflammatory activities. In addition, leukocytosis, lymphocytosis were recorded as spirulina supplementation might stimulate the activity of the bone marrow stem cells and consequently strengthen systemic and particularly immune cellular defenses of the organism (Jensen et al., 2000) or increased zinc concentration in spirulina (Abou- Zeid et al., 1999) so it has immunostimulating effect. This result is also supported by increase antibody titer against newcastle disease virus and increased concentrations of plasma globulin which are thought to be associated with a potent innate response and indicate higher resistance (Matanovic et al., 2007). Similarly, spirulina was reported to enhance the Phagocytosis activity of heterophils in peripheral circulation. These results are agreed with (Jensen et al., 2001).

Furthermore, spirulina supplementation seems to preserve the structural integrity of the hepatocellular membrane in preventive group more than therapeutic group which indicated by decreased level of AST, ALP, cholesterol and increase level of total protein, albumin as compared with diclofenac treated group which occur as spirulina posses strong antioxidant such as vitamins, carotenoid and phycocyanin (Upasani and Balaraman, 2003) and free radical scavenging properties (Chu et al., 2010; Ismail et al., 2009) and (Gad et al., 2011). Significant reduction in uric acid level was recorded through protective effect of spirulina in restoring glomerular filtration against diclofenac toxicity. Similar results were obtained by ((Abdel-Daim et al., 2013).

In addition, spirulina supplementation was observed to exhibit hepatoprotective effect more potent in preventive group than therapeutic group as demonstrated by restoring antioxidant enzymes (superoxide dismutase, catalase and total antioxidant capacity) and diminish MDA and NO level against diclofenac induce hepatotoxicity in chicks (Karadeniz et al., 2009) and (Abdelkhalek et al., 2015).

The antioxidative effect of spirulina is related to several active ingredients, Vitamin $\mathrm{C}$ and $\mathrm{E}, \beta$ carotene, superoxide dismutase, selenium and brilliant blue polypeptide pigment phycocyanin which have been known as a potent inhibitor of lipid peroxide formation, a scavenger of hydroxyl and superoxide radicals, and to increase the antioxidant enzymes (El-Demerdash, 2001) and (Sharma et al., 2012). The hepatoprotective role of phycocyanin could be referred to inhibition of some of the cytochrome P450 mediated reactions involved in the formation of reactive metabolites or its ability to act as an efficient radical scavenger or both (Bhat and Madyastha, 2000), (Megret and Torres, 2006). Vitamin E present in spirulina traps lipid peroxyl and other radicals and effectively inhibits the peroxidation of cellular membranes and maintains GSH and ascorbic acid levels in damaged tissue by inhibiting free radicals formation (Gemma et al., 2002). Several investigators stated that $\beta$-carotene of spirulina may reduce cell damage (Alvarenga et al., 2011).

Histopathological findings in livers tissues go side by side with the obtained hematological, biochemical and antioxidant alterations. Histopathological examinations of diclofenac treated group showed marked congestion of hepatic blood sinusoids associated with multifocal hepatic degeneration and sinusoidal cell activation (Meteyer et al., 2005) and (Patel et al., 2007) these adverse effects may be contributed to oxidative stress induced by the drug. Furthermore, these results are agreement with those obtained by (Triebskorn et al., 2004) and (Hussain et al., 2008).

On the other side, the histopathological studies of liver tissue of chicks that were treated with spirulina in therapeutic group recorded vacuolation of hepatocytes with periportal hepatic single cell degeneration. Whereas, chicks treated with spirulina in preventive group were apparently normal as 
compared to the chicks that were treated with diclofenac sodium which are similar to histopathological changes recorded by (Jeyaprakash and Chinnaswamy, 2005) and (Amin et al., 2006) this occur due to spirulina posse's antioxidant armory and free radical scavenging effect (Bermejo et al., 2008).

In summary, Spirulina supplementation could be used as a preventive dietary supplementation against diclofenac sodium induced hepatotoxicity. Further research is required for under standing the mechanism of action of Spirulina for providing protection against diclofenac sodium induced hepatotoxicity.

\section{REFERENCES}

Abdel-Daim, M.M.; Abuzead, S.M. and Halawa, S.M. (2013): Protective role of Spirulina platensis against acute deltamethrin-induced toxicity in rats. PLoS One 8, e72991.

Abdelkhalek, N.K.; Ghazy, E.W. and Abdel-Daim, M.M. (2015): Pharmacodynamic interaction of Spirulina platensis and deltamethrin in freshwater fish Nile tilapia, Oreochromis niloticus: impact on lipid peroxidation and oxidative stress. Environ Sci Pollut Res Int 22, 3023-3031.

Abou- Zeid, A.E.; Mohamed, F.F.; Sabira, B. and Abou EL-Soud (1999): Impact of vitamin and or zinc supplementation on performance and immunity of broilers. Egypt Poultry Sci. J. 19, 635-655.

Adebayo, A.; Abolaji, A.; Opata, T. and Adegbenro, I. (2010): Effects of ethanolic leaf extract of Chrysophyllum albidum G. on biochemical and haematological parameters of albino wistar rats. Afr J. Biotechnol 9, 2145-2150.

Alvarenga, R.; PB, R.; Cantarelli, VS.; Zangeronimo, MG.; Junior, JWS.; Silva, LR.; Santos LM. and $L J, P$. (2011): Energy values and chemical composition of spirulina (Spirulina platensis evaluated with broilers. Rev Bras Zootec 40, 992-996.

Amin, A.; Alaa Eldin A. Hamzal, Daoud, S. and Hamza, W. (2006): Spirulina protects against cadmium-induced hepatotoxicity in rats. Am. J. Pharm. Toxicol 1, 21-25.

Bakke, O.M.; Manocchia, M.; De Abajo, F.; Kaitin, K.I. and Lasagna, L. (1995): Drug safety discontinuations in the United Kingdom, the United States, and Spain from 1974 through 1993: a regulatory perspective. Clinical Pharmacology\& Therapeutics 58, 108-117.

Bancroft, J.D.; Cook, H.C. and Beckstead, J.H. (1996): Manual of histological techniques and their diagnostic application. Archives of Pathology and Laboratory Medicine 120, 986986.

Bermejo, P.; Pinero, E. and Villar, A.M. (2008): Ironchelating ability and antioxidant properties of phycocyanin isolated from a protean extract of Spirulinaplatensis. Food Chem 110, 436-445.

Bhat, V.B. and Madyastha, K.M. (2000): Cphycocyanin: a potent peroxyl radical scavenger in vivo and in vitro. Biochem Biophys Res Commun 275, 20-25.

Chauhan, R.S. and Chandra, D. (2007): Veterinary laboratory Diagnosis. Second revised and enlarged edition. 11-123.

Chu, W.L.; Lim, Y.W.; Radhakrishnan, A.K. and Lim, P.E. (2010): Protective effect of aqueous extract from Spirulina platensis against cell death induced by free radicals. BMC Complement Altern Med 10, 53.

Coles, H.E.F.E. (1986): Veterinary Clinical Pathology. W.B. Saunders Company Philadelphia, London, Toronto, Mexico city, Rio de Janeiro, Sydney, Tokyo, and Hong Kong.

El-Demerdash, F.M. (2001): Effects of selenium and mercury on the enzymatic activities and lipid peroxidation in brain, liver, and blood of rats. $\mathbf{J}$ Environ Sci Health B 36, 489-499.

Eldin, A.A.; Shaheen, A.A.; Abd Elgawad, H.M. and Shehata, N.I. (2008): Protective effect of taurine and quercetin against renal dysfunction associated with the combined use of gentamycin and diclofenac. Indian J Biochem Biophys 45, 332-340.

Esterbauer, H.K.H.; Cheeseman, M.U.; Dianzani, G.; Poli and Slater, T.F. (1982): Separation and characterization of the aldehydic products of lipid peroxidation stimulated by ADP-Fe2+ in rat liver microsomes. Biochem. J 208, 129140 .

Gad, A.S.; Khadrawy, Y.A.; El-Nekeety, A.A.; Mohamed, S.R.; Hassan, N.S. and AbdelWahhab, M.A. (2011): Antioxidant activity and hepatoprotective effects of whey protein and Spirulina in rats. Nutrition 27, 582-589.

Gemma, C.; Mesches, MH.; Sepesi, B.; Choo, K.; Holmes, DB. and PC, B. (2002): Diet enriched in foods with high antioxidant activity reverse age-induced decreases in cerebellar-adrenergic function and increases in proinflammatory cytokines. J Neuro sci 22, 6114-6120.

Hosseini, S.; Khosravi, D.K. and MR., M. (2013): Nutritional and medical application of spirulina microalgae. Mini Rev Med Chem 13, 1231-1237.

Hussain, I.; Khan, M.Z.; Khan, A.; Javed, I. and Saleemi, M.K. (2008): Toxicological effects of diclofenac in four avian species. Avian Pathol 37, 315-321.

Ismail, M.F.; Ali, D.A.; Fernando, A.; Abdraboh, M.E.; Gaur, R.L.; Ibrahim, W.M.; Raj, M.H. and Ouhtit, A. (2009): Chemoprevention of rat liver toxicity and carcinogenesis by Spirulina. Int J Biol Sci 5, 377-387.

Jensen, G.S.; D.I., G. and Drapeau, C. (2001): Bluegreen algae as an immuno-enhancer and 
biomodulator. J. Am. Nutraceutical Assoc 3, 24-30.

Jensen, G.S.; Ginsberg, D.I.; Huertap, Citton, M. and Drapeau, M. (2000): Consumption of Aphanizomenon flosaquae have rapid effects on the circulation and function of immune cells in humans. A novel approach to nutritional mobilization of the immune system. J. Am. Nutraceutical Assoc 2, 50-58.

Jeyaprakash, K. and Chinnaswamy, P. (2005): Effect of spirulina and Liv-52 on cadmium induced toxicity in albino rats. Indian J. Exp Biol 43, 773-781.

Karadeniz, A.; Cemek, M. and Simsek, N. (2009): The effects of Panax ginseng and Spirulina platensis on hepatotoxicity induced by cadmium in rats. Ecotoxicol Environ Saf 72, 231-235.

Kenneth, S.L.; A.M., E. and W.P, A.K. (2003): Duncan and Prasse's Veterinary Laboratory Medicine Clinical Pathology. Fourth Edition. , 47-79.

King, D.J. and Seal, B.S. (1998): Biological and Molecular characterization of Newcastle disease virus (NDV) field isolates with comparisons of reference NDV strains and pathogenicity chicken or embryo passage of selected isolates. Avian Dis. 42, 507-516.

Koracevic, D.; Koracevic, G.; Djordjevic, V.; Andrejevic, S. and Cosic, V. (2001): Method for the measurement of antioxidant activity in human fluids. J Clin Pathol 54, 356-361.

Luo, A.; Feng, J.; Hu, B.; Lv, J.; Chen, C.O. and Xie, $S$. (2017): Polysaccharides in Spirulina platensis Improve Antioxidant Capacity of Chinese-Style Sausage. J. Food Sci.

Matanovic, K.; Severin, K.; Martinkovic, F.; Simpraga, M.; Janicki, Z. and Barisic, J. (2007): Hematological and biochemical changes in organically farmed sheep naturally infected with Fasciola hepatica. Parasitol Res 101, 1657-1661.

Megret, R.A. and Torres, M.A.B. (2006): Spirulina platensis as scavenger of the reactive oxygen species. Pharmacology 3, 611-616.

Meteyer, C.U.; Rideout, B.A.; Gilbert, M.; Shivaprasad, H.L. and Oaks, J.L. (2005): Pathology and proposed pathophysiology of diclofenac poisoning in free-living and experimentally exposed oriental white-backed vultures (Gyps bengalensis). J Wildl Dis 41, 707-716.

Mohan, K.; Jayakumar, K.; Narayanaswamy, H.D.; Manafi, M. and Pavithra, B.H. (2012): An initial safety assessment of hepatotoxic and nephrotoxic potential of intramuscular ketoprofen at single repetitive dose level in broiler chickens. Poult Sci 91, 1308-1314.

Montgomery, H. and Dymock, F. (1961): Determination of nitrite in water. Analyst, 86, 414-416.
Packer, L. and Glazer, A.N. (1990): Methods in Enzymology, Oxygen Radicals in Biological Systems Part B: Oxygen Radicals and Antioxidants. Academic Press, New York, 186: 251.

Patel, A.; DJ, G.; Dave, CJ; PB, J.; BP, J. and P.K., (2007): Experimental studies on etiopathology of visceral gout in broiler chicks. Indian J Vet Pathol 31, 16-24.

Ponce-Canchihuaman, J.C.; Perez-Mendez, O.; Hernandez-Munoz, R.; Torres-Duran, P.V. and Juarez-Oropeza, M.A. (2010): Protective effects of Spirulina maxima on hyperlipidemia and oxidative-stress induced by lead acetate in the liver and kidney. Lipids Health Dis 9, 35.

Prakash, R.N.C.; Anjaneyulu, Y.; Sivasankari, B. and A., R.K. (2006): Comparative toxicity studies in birds using nimesulide and diclofenac sodium. Environ. Toxicol. Pharmacol. 22, 142-147.

Rasool, M.; Sabina, E.P. and Lavanya, B. (2006): Anti-inflammatory effect of Spirulina fusiformis on adjuvant-induced arthritis in mice. Biol Pharm Bull 29, 2483-2487.

Reitman, S. and Frankel, S. (1957): A colorimetric method for the determination of serum glutamic oxalacetic and glutamic pyruvic transaminases. Am J Clin Pathol 28, 56-63.

Richmond, W. (1973): Enzymatic determination of cholesterol. Clin. Chem., 19, 1350.

Sachs, U.J.; Santoso, S.; Roder, L.; Smart, E.; Bein, G. and Kroll, H. (2004): Diclofenac-induced antibodies against red blood cells are heterogeneous and recognize different epitopes. Transfusion 44, 1226-1230.

Sanchez, S.; Alarcon de la Lastra, C.; Ortiz, P.; Motilva, V. and Martin, M.J. (2002): Gastrointestinal tolerability of metamizol, acetaminophen, and diclofenac in subchronic treatment in rats. Dig Dis Sci 47, 2791-2798.

Sharma, K.P.; Upreti, N.; Sharma, S. and Sharma, S. (2012): Protective effect of Spirulina and tamarind fruit pulp diet supplement in fish (Gambusia affinia Baird \& Girard) exposed to sublethal concentration of fluoride, aluminum and aluminum fluoride,". Indian Journal of Experimental Biology 50, 897-903.

Sinha, A.K. (1972): Colorimetric assay of catalase. Anal. Biochem, 47, 389-394.

Sunilson, J.A.J.; Muthapaan, M.; Das, A. and Suraj, R. (2009): Hepatoprotective activity of Coccinia grandis leaves against carbon tetrachloride induced hepatic injury in rats. International H. Pharmaco 1, 222-227.

Swan, G.E.; Cuthbert, R.; Quevedo, M.; Green, R.E.; Pain, D.J.; Bartels, P.; Cunningham, A.A.; Duncan, N.; Meharg, A.A.; Oaks, J.L.; ParryJones, J.; Shultz, S.; Taggart, M.A.; Verdoorn, $G$. and Wolter, K. (2006): Toxicity of diclofenac to Gyps vultures. Biol Lett 2, 279282. 
Swetha, R., K., Jayakumar, H.D., Narayanaswamy, L.V., Lokesh, a.N., M. (2005): Toxicity study of diclofenac in broiler chickens. Page 34 in Proceedings of the Fifth Annual Conference of Indian Society of Veterinary Pharmacology and Toxicology. Chennai, India.

Syed, N.I.; Zehra, F.; Syed, A.A.; Karim, S. and Khan, F.Z. (2012): Comparing the effects of salts of diclofenac and alminoprofen with aspirin on serum electrolytes, creatinine and urea levels in rabbits. Pak J Pharm Sci 25, 777-782.

Thirunavukkarasu, $\quad$ V.; Balakrishnan, S.D.; Ravichandran, M.K. and Anuradha, C.V. (2003): Influence of 6-week exercise training on erythrocyte and liver antioxidant defense in hyperinsulinemic rats. Comp Biochem Physiol C Toxicol Pharmacol 135, 31-37.

Tietz, N.W.; Burtis, C.A.; Duncan, P.; Ervin, K.; Petitclerc, C.J.; Rinker, A.D.; Shuey, D. and Zygowicz, E.R. (1983): A reference method for measurement of alkaline phosphatase activity in human serum. Clin Chem 29, 751-761.

Triebskorn, R.; Casper, H.; Heyd, A.; Eikemper, R.; Kohler, H.R. and Schwaiger, J. (2004): Toxic effects of the non-steroidal anti-inflammatory drug diclofenac. Part II: cytological effects in liver, kidney, gills and intestine of rainbow trout (Oncorhynchus mykiss). Aquat Toxicol 68, 151-166.

Upasani, C.D. and Balaraman, R. (2003): Protective effect of Spirulina on lead induced deleterious changes in the lipid peroxidation and endogenous antioxidants in rats. Phytother Res 17, 330-334.

Venkateswaran, S. and Pari, L. (2003): Effect of Coccinia indica leaves on antioxidant status in streptozotocin-induced diabetic rats. J. Ethnopharmacol 84, 163-168.

Wilkinson, P.C. (1981): Techniques in clinical immunology.2nd ed., Black well scientific publications, London, PP 287-288.

Wu, Q.; Liu, L.; Miron, A.; Klimova, B.; Wan, D. and Kuca, K. (2016): The antioxidant, immunomodulatory, and anti-inflammatory activities of Spirulina: an overview. Arch Toxicol 90, 1817-1840.

Yapar, K.; Atakisi, O.; Uzlu, E.; Citil M, M, U., H, M.E., (2008): Protective effect of L - carnitine against diclofenac sodium toxicity in mice. Rev. Med. Vet 159, 363-367.

\section{التأثير التحسني للسبيرولينا بلاتنسيس ضد السمية الكبدية الناجمة عن ديكلوفيناك الصوديوم في دجاج

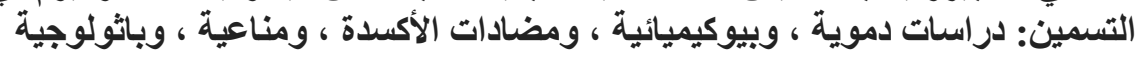

\section{عبل الله احد مخبطلي ، عماد وديإ غازي ، دعاء حسني عبل الهادي ، عبله وليب ، مروه عبل الوهاب عبل الهنعم}

Email: doaa_assar2000@yahoo.com Assiut University web-site:www.aun.edu.eg

يعد طحلب الاسبيرولينا احد المكملات الغذائية الأكثر شيو عا في تربية الأحباء المائية ، وصناعه الدو اجن ، و اكتسب مزيدا من الاهتمام

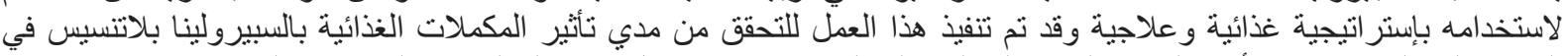

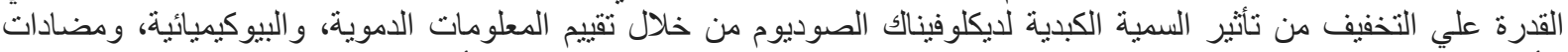

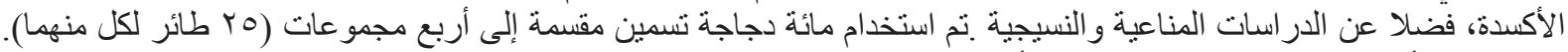

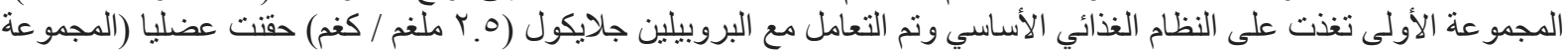

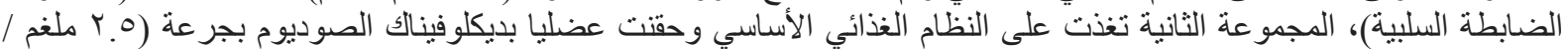

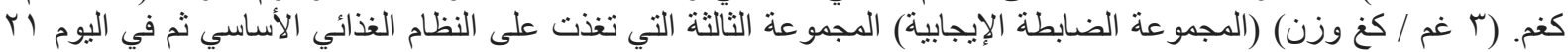

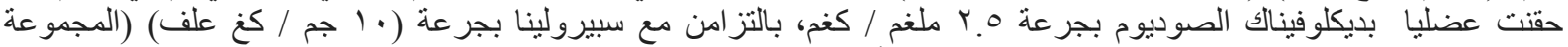

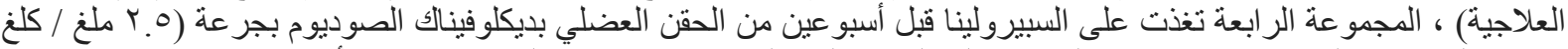

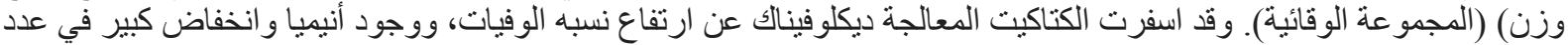

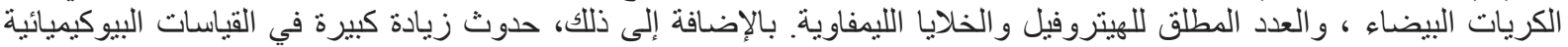

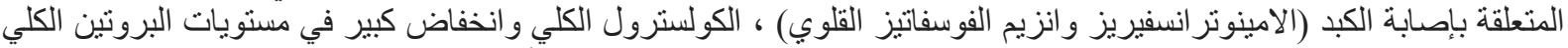

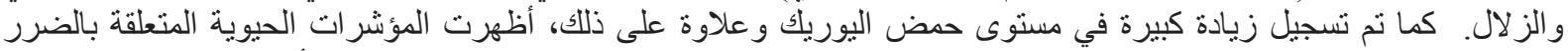

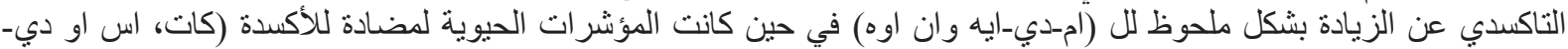

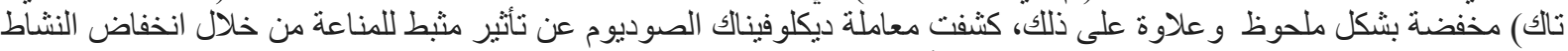

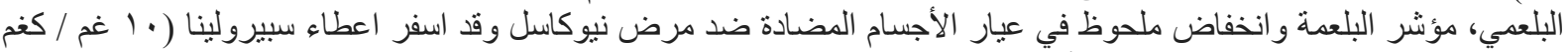

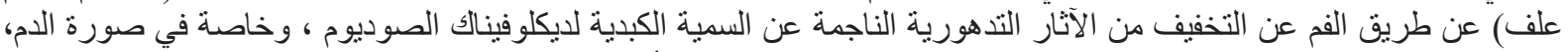

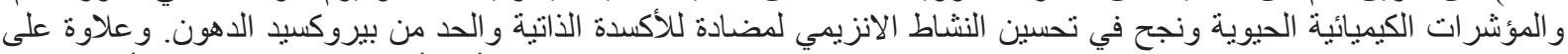

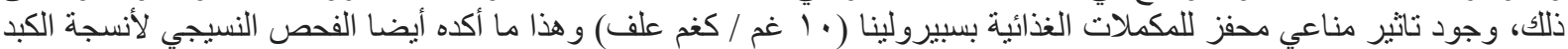

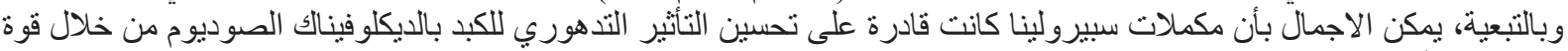

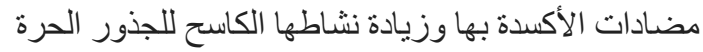

